DOI 10.32726/2411-3417-2018-1-81-95

УДК 327; 339

\title{
НАиля ЯКОВЛЕВА
}

\section{Российско-аргентинское партнерство в глобальном и региональном контексте}

Аннотачия. В условиях глобальной нестабильности и меняющегося миропорядка возникли факторы, объективно способствующие сближению Российской Федерации с теми регионами мира, которые еще недавно находились исключительно в сфере интересов других мировых акторов. Речь идет, в частности, о регионе Латинской Америки и Карибского бассейна (ЛАКБ), в отношениях с которым в 2017 г. произошел своеобразный прорыв. Одним из главных и перспективных партнеров РФ становится Аргентина страна, с которой Россию связывают давние торговые, культурные и гуманитарные связи.

Ключевые слова: Россия, Латинская Америка и Карибский бассейн, Аргентина, торгово-экономическое сотрудничество, стратегическое партнерство.

D оссия поддерживает дипломатические отношения со всеми 33 государствами Латинской Америки и Карибского бассейна (ЛАКБ). По информации МИД РФ, там действует 18 российских посольств и 3 генконсульства, в 15 странах российские послы аккредитованы по совместительству. В России функционирует 19 латиноамериканских посольств [0 состоянии...].

На состоявшейся 6 декабря 2017 г. традиционной встрече министра иностранных дел РФ С.В. Лаврова с латиноамериканским дипкорпусом стороны смогли отметить существенное продвижение по пути многостороннего взаимодействия практически во всех возможных форматах и сферах сотрудничества. Например, с семью странами (Аргентиной, Бразилией, Венесуэлой, Кубой, Никарагуа, Перу и Эквадором) Россия имеет соглашения о стратегическом партнерстве. С большинством государств Южной и Центральной Америки заключены межправительственные соглашения об условиях отказа от визовых формальностей'.

Можно выделить несколько отличительных черт современных отношений России с регионом в сравнении с тем временным отрезком, когда наша страна делала ставку на поддержку определенных политических режимов, прежде всего кубинского. Вопервых, отношения РФ со странами ЛАКБ носят все более прагматический характер.

1 С Аргентиной, Бразилией, Венесуэлой, Гайаной, Гватемалой, Гондурасом, Колумбией, Никарагуа, Панамой, Парагваем, Перу, Уругваем, Чили, Эквадором, Боливией и Сальвадором.

Сведения о6 авторе: ЯКОВЛЕВА Наиля Магитовна - ведущий научный сотрудник Центра политических исследований Института Латинской Америки (ИЛА) РАН, кандидат исторических наук; nel-yakovleva@yandex.ru. 
Регион рассматривается российским руководством не как поле идеологических битв, а как огромный рынок для российских товаров, технологий и инвестиций. Во-вторых, Россия не ограничивается только двусторонними отношениями со странами региона и освоила сотрудничество с ними в многостороннем формате (в БРИКС, Группе двадцати, АТЭС ${ }^{1}$ и др.), а также проявляет интерес к взаимодействию с региональными интеграционными группировками (например, МЕРКОСУР²). В 2015 г. был создан постоянный механизм политического диалога с СЕЛАКㄱ. Россия подала официальную заявку на присоединение в качестве внерегионального наблюдателя к ЦАИС 4 .

Новому позиционированию России в латиноамериканском регионе способствовал ряд причин, которые можно условно разделить на две группы. В первую входят факторы ослабления влияния традиционных партнеров ЛАКБ: освобождение «площадки» главным глобальным игроком - Соединенными Штатами Америки [Яковлев Эффект...], а также существенные трудности в развитии диалога с Европой, в первую очередь со странами ЕС. Во вторую - моменты, способствующие сближению России с государствами ЛАКБ: совпадение или близость взаимных интересов в совершенствовании существующего миропорядка. Речь идет о таких ключевых сферах, как мировая экономика и торговля, кредитно-финансовая область, глобальная безопасность и борьба с наркотрафиком и террористической угрозой в условиях возросшей глобальной напряженности и нестабильности. Россия и Латинская Америка проявляют интерес к сотрудничеству в военно-технической области, энергетике, космической отрасли, налаживают взаимодействие в деле предотвращения и ликвидации последствий стихийных бедствий и чрезвычайных ситуаций, расширяют контакты и реализуют совместные программы в гуманитарной сфере. Не последнюю роль в деле сближения РФ и ЛАКБ играют факторы «второго ряда» - такие, как неприсоединение государств региона к антироссийским санкциям коллективного Запада. Все это в совокупности открывает новые возможности для интенсификации торгово-экономического и инвестиционного сотрудничества России с этим регионом мира.

В 2017 г. стало очевидным то, о чем много лет писали в своих трудах специалисты по Латинской Америке [См. напр.: Астахов; Давыдов; Яковлев Россия...]: страны ЛАКБ

1 АТЭС - Азиатско-Тихоокеанское экономическое сотрудничество (англ. Asia-Pacific Economic Cooperation, APEC) - форум 21 страны Азиатско-Тихоокеанского региона для сотрудничества в области региональной торговли и облегчения и либерализации капиталовложений.

2 МЕРКОСУР - Общий рынок стран Южной Америки (исп. Mercado Común del Sur, Mercosur). Существует с 1991 г., в него входят Бразилия, Аргентина, Парагвай, Уругвай. Членство Венесуэлы было приостановлено. Ассоциированные члены - Чили, Колумбия, Эквадор, Перу. Мексика и Новая Зеландия имеют статус официальных наблюдателей.

3 СЕЛАК - Сообщество стран Латинской Америки и Карибского бассейна (исп. Comunidad de Estados Latinoamericanos y Caribeños, CELAC). Региональный блок создан в 2010 г. Входят все независимые государства Северной, Центральной и Южной Америк, за исключением США и Канады.

4 ЦАИС - Центральноамериканская интеграционная система (исп. El Sistema de la Integración Centroamericana, SICA). Создана в 1991 г. Члены ЦАИС - Коста-Рика, Сальвадор, Гватемала, Гондурас, Никарагуа, Панама, Белис, Доминиканская Республика. Существует группа региональных и экстрарегиональных наблюдателей. 
представляют собой естественного, потенциально выгодного, а в современных специфических и крайне противоречивых условиях - уникального партнера Российской Федерации на международной арене, готового к длительному плодотворному и разностороннему диалогу и взаимодействию в разнообразных форматах.

В числе наиболее перспективных партнеров России фигурирует Аргентина. «Аргентинская Республика - одна из самых крупных и развитых стран Латинской Америки, играющая заметную роль в мировых делах и в течение десятилетий занимающая видное место в общем контексте международных связей СССР и Российской Федерации. Именно эти обстоятельства в первую очередь определяют то большое значение, которое имеет Аргентина с точки зрения задач национального развития современной России», - справедливо отмечали российские исследователи [См., напр.: Яковлев Тенденции...].

\section{Из истории российско-аргентинских отношений}

Дипломатические отношения Аргентины с Россией были установлены 132 года назад - 22 октября 1885 года. С этого времени в Аргентине сменились 17 Чрезвычайных и Полномочных послов нашей страны ${ }^{1}$, состоялись визиты высшего и высокого уровня, подписано множество двусторонних документов, сложились форматы торгово-экономического сотрудничества, налажены гуманитарные связи.

В истории двусторонних отношений можно выделить три крупных этапа:

- отношения между Аргентиной и Российской империей (1885-1917 гг.);

- отношения между Аргентиной и СССР (1917-1991 гг.);

- Отношения между Российской Федерацией и Аргентинской Республикой (1991-настоящее время).

Третий, современный этап двусторонних отношений, в свою очередь, можно разделить на три различных по содержанию периода. Если в течение первого периода (1991-2007 гг.) отношения между Россией и Аргентиной характеризовались постепенным сближением, то в 2008-2014 гг. они были подняты до уровня стратегического партнерства. Начиная с 2015 г. (нынешний период) аргентино-российские отношения перешли в фазу всеобъемлющего стратегического партнерства.

\section{Период сближения (1991-2007 гг.)}

Как это ни парадоксально, первые 100 лет история отношений России и Аргентины развивалась без встреч на высшем политическом уровне. Ни один глава государства, российского (советского) или аргентинского, с момента взаимного дипломатического

1 В настоящее время посол РФ в Аргентине - Виктор Викторович Коронелли (с июля 2011 г.), посол Аргентины в РФ - Рикардо Эрнесто Лагорио (с июня 2017 г.) - URL: argentina.mid.ru/ embajadores; argentina.mid.ru/posol; efrus.mrecic.gov.ar/representaciones/repre/92 (date of acces: 19.12.2017). 
признания не нашел достаточных оснований и возможностей для того, чтобы преодолеть немалое расстояние, разделяющее наши страны. Однако в последние 30 лет ситуация кардинально изменилась. К власти в обеих странах пришли более активные и открытые миру политические лидеры. Это немаловажное субъективное обстоятельство, вкупе с объективными причинами политико-экономического порядка, способствовало началу прямого диалога между высшими государственными лицами Аргентины и сначала СССР, а затем России в формате официальных визитов.

Первые шаги в этом направлении предприняла аргентинская сторона. Через три года после восстановления в Аргентине демократического правления (по завершении периода военной диктатуры), в 1986 г., состоялся визит президента Рауля Альфонсина в СССР. В 1990 г. его примеру последовал новый президент Карлос Менем, демонстрируя интерес своего правительства к развитию отношений с нашим государством. В декабре 1991 г., после распада Советского Союза, Российская Федерация была признана аргентинским правительством в качестве государства-правопреемника СССР. В 1998 г. вторично избранный на пост президента К. Менем повторил свой визит, что было свидетельством реального стремления к наращиванию сотрудничества с новой демократической Россией.

В ходе трех перечисленных визитов была создана солидная договорно-правовая база взаимодействия, заключено 17 соглашений. В частности, был подписан важнейший документ - Соглашение об основах отношений между Российской Федерацией и Аргентинской Республикой от 25 июня 1998 г., заложивший фундамент двустороннего сотрудничества. Это дало импульс расширению спектра российско-аргентинского взаимодействия, привело к активизации политических, научных и культурных контактов.

Но не все было гладко. В 1990-е годы, в условиях проведения в обеих странах экономических реформ неолиберального толка, произошло падение объема взаимной торговли. Старые схемы экономических связей перестали работать. Было очевидно, что взаимоотношения нуждаются в обновлении и переформатировании.

Благоприятные условия для активизации сотрудничества сложились в середине первого десятилетия нового века. Россия преодолела тяжелые последствия дефолта 1998 г. и стала резко наращивать экономическую мощь. Аргентина, в свою очередь, пережила глубокий кризис 2001-2002 гг. и, изменив модель социально-экономического развития, встала на путь модернизации и диверсификации экономики. Министерства иностранных дел двух стран провели ревизию всех двусторонних договоров, в результате чего был подготовлен и подписан межправительственный Протокол о действии договоров, заключенных между СССР и Аргентиной. Договорно-правовая база отношений была актуализирована. Для полноценного рывка недоставало еще двух компонентов: стратегического решения правительств об интенсификации межгосударственного диалога и личных встреч высших руководителей государств. Катализатором российско-аргентинского сближения стали изменения во внутриполитической ситуации обеих стран и необходимость их нового позиционирования на международной арене. 


\section{Установление отношений стратегического партнерства (2008-2014 гг.)}

2008 г. можно назвать пороговым в отношениях нашей страны с Латинской Америкой в целом. В Концепции внешней политики РФ, утвержденной 12 июля 2008 г., было определенно выражено стремление Москвы наращивать политическое и экономическое сотрудничество со странами ЛАКБ, расширять взаимодействие с ними в международных организациях, поощрять экспорт в регион российской наукоемкой промышленной продукции, осуществлять совместные проекты в сфере энергетики, инфраструктуры, высоких технологий, в том числе в рамках планов, разрабатываемых в региональных интеграционных объединениях [Концепция...]. С принятием данной Концепции отношения с Аргентиной вступили в новый этап и стали развиваться по нарастающей. Произошла беспрецедентная активизация политических контактов, интенсифицировались встречи высших руководителей, между которыми установились доверительные отношения, демонстрировалась готовность к длительному взаимодействию. Только за период с 2008 по 2015 гг. состоялось четыре официальных визита президентов обеих стран.

Первым аргентинским президентом, посетившим Россию в XXI в., стала Кристина Фернандес де Киршнер. Ее визит состоялся 9-10 декабря 2008 г. и был реализован в момент, когда обе страны находились в поисках эффективных форм и нового качества партнерства, стремились к выходу из узкого коридора традиционных связей и рынков на более перспективные торговые и инвестиционные пространства. По итогам переговоров руководители двух государств подписали «Совместное заявление Российской Федерации и Аргентинской Республики о построении отношений стратегического партнерства». В документе ставилась задача «углублять политический диалог в двустороннем и многостороннем формате с целью продвижения совместных интересов на международной арене», перечислялись приоритетные сферы будущего экономического взаимодействия [Совместное заявление...]. 23 сентября 2009 г. «на полях» 64-й сессии ГА ООН в Нью-Йорке министры иностранных дел России (С.В. Лавров) и Аргентины (Х. Тайана) во исполнение достигнутых на высшем уровне договоренностей подписали «План действий по построению отношений стратегического партнерства».

В апреле 2010 г. состоялся первый за всю историю российско-аргентинских отношений официальный визит в Аргентину президента нашей страны. В «Совместном заявлении Президентов Российской Федерации и Аргентинской Республики в год 200-летия Майской революции и 125-летия установления двусторонних дипломатических отношений» Д.А. Медведев и К. Фернандес де Киршнер выразили удовлетворение успешным продвижением по пути построения отношений стратегического партнерства. В ходе визита были подписаны 12 межведомственных соглашений и меморандумов, охватывавших многие сферы двустороннего сотрудничества. Всего же в результате обмена визитами руководителей двух стран в 2008 и 2010 г. был подписан 21 документ, что вывело Россию на первое место среди стран за пределами латиноамериканского региона по количеству двусторонних соглашений с Аргентиной [Яковлева Договорная...]. Продвижение вперед в реализации «Плана действий», совместная работа на международных форумах, укрепление торгово-экономических связей позволили по- 
слу Аргентины в РФ в 2011-2013 гг. Х.К. Креклеру выразить мнение, что отношения между двумя странами «переживают лучший момент» в их истории [Las relaciones...].

Важно, что в последнее десятилетие аргентино-российские отношения заметно диверсифицировались. Это проявилось в увеличении торгово-экономических и научнотехнических обменов, новаторских формахвзаимодействияв области бизнеса, культуры, спорта и средств массовых коммуникаций. На пространстве двусторонних отношений, наряду с традиционными игроками - государствами, их институтами и предприятиями, укрепились и расширили свое влияние новые акторы: частные промышленные, торговые и сельскохозяйственные компании, банки, объединения предпринимателей, разного рода консалтинговые организации, юридические и посреднические фирмы, СМИ и другие социальные субъекты, включая так называемых «неорганизованных» лиц. В 2009 г. для облегчения взаимодействия было подписано двустороннее межправительственное «Соглашение о безвизовых поездках граждан». Аргентино-российские связи охватили практически все сферы деятельности, постепенно приобретая черты реального стратегического партнерства.

\section{Переход к всеобъемлющему стратегическому партнерству}

Огромный вклад в этот процесс внесли премьер-министры, министры иностранных дел, дипломатический корпус, парламентарии. Большую роль сыграли усилия руководства госкорпораций и частных предприятий. Нельзя недооценивать и заслуги гражданского общества, деятелей науки и культуры, успешно развивавших гуманитарные связи. Однако в первую очередь стратегический прорыв стал возможным благодаря успешной президентской дипломатии.

Новый импульс двусторонним отношениям придал официальный визит в страны Латинской Америки, включая Аргентину, президента России В.В. Путина. Накануне своей поездки в июле 2014 г. президент подчеркнул, что плодотворная работа, проводившаяся на основе «Плана действий», принятого в 2009 г., позволила достичь «высокого уровня выполнения предусмотренных в нем шагов» [Интервью...].

По сути, период с 2009 до 2014 г. явился переходным этапом к отношениям всеобъемлющего стратегического партнерства. Регулярное взаимодействие глав государств и внешнеполитических ведомств, представителей законодательной власти, прямые контакты деловых кругов, повышенный интерес к раскрывающимся перспективам сотрудничества со стороны государственных корпораций способствовали развитию двусторонних связей в целом. Интенсивно велась работа по расширению договорно-правовой базы. За это время был подготовлен ряд документов, подписанных по итогам российско-аргентинских переговоров на высшем уровне в 2014 г. В их числе: договоры между Российской Федерацией и Аргентинской Республикой «о взаимной правовой помощи по уголовным делам» и «о передаче для отбывания наказания лиц, осужденных к лишению свободы»; «Соглашение между Правительством Российской Федерации и Правительством Аргентинской Республики о сотрудничестве в области использования атомной энергии в мирных целях»; «Соглашение о сотрудничестве в об- 
ласти массовых коммуникаций между Министерством связи и массовых коммуникаций РФ и Государственным секретариатом по общественным коммуникациям Аргентинской Республики» т.д. «Мы развиваем отношения с Аргентиной по всем направлениям», сказал по завершении визита российский президент. - Это касается и политического уровня, это касается гуманитарных связей, экономики» [Заявления...].

В ходе визита обсуждались и международные проблемы, как представляющие взаимный интерес, так и касающиеся положения каждого из партнеров в мире. Аргентина в тот момент пыталась разрубить «гордиев узел» в отношениях с зарубежными хеджфондами, Россия испытывала давление режима санкций-антисанкций из-за украинской ситуации. Поэтому поддержка Россией борьбы аргентинского президента с международным финансовым капиталом была оценена высоко и, более того, повлияла на позицию Аргентины по «крымскому» вопросу. Недаром российский президент признал, что эта южноамериканская страна является для нашей страны «комфортным партнером».

Успех визита В.В. Путина и достижение договоренностей в области торгово-экономического сотрудничества предопределили тот реальный прорыв, который произошел в ходе ответного визита аргентинского президента в Москву в апреле 2015 г. В результате достигнутых договоренностей двусторонние отношения перешли на новый уровень, что было отражено в Совместной декларации и сопровождавшем ее обновленном Плане действий по построению отношений всеобъемлющего стратегического партнерства. Речь шла об актуальных международных вопросах, по которым стороны хотели ли бы заручиться взаимной поддержкой (так называемый «мальвинский вопрос» и ситуация в Южной Атлантике [Яковлева Архипелаг...], невмешательство третьих стран во внутриполитические дела, взаимный отказ от признания возможных государственных переворотов, мирное разрешение украинского кризиса и пр.).

Конкретным содержанием российско-аргентинского партнерства становилось веерное расширение торгово-экономического сотрудничества в таких важнейших сферах, как космос, ядерная энергетика, разработка недр, высокие технологии, аграрный сектор, промышленность и транспорт, экология, массовые коммуникации, гидроэнергетика, наука и образование, культура, спорт, туризм, правовая сфера и пр. Логика развития отношений подсказывала, что пора переходить от «классического» товарообмена к многопрофильному промышленно-инвестиционному взаимодействию, добиваться реализации масштабных двусторонних проектов, которые могли бы расчистить поле для активного производственного и технологического партнерства.

В общей сложности во время визита К. Фернандес де Киршнер было подписано два десятка межгосударственных, межправительственных, межбанковских и других документов [Síntesis...]. Стоит отметить подписание межправительственных соглашений, укрепляющих договорно-правовую базу: «о взаимной защите секретной информации в сфере военно-технического сотрудничества» и «о сотрудничестве в области охраны окружающей среды». Страны договорились взаимодействовать и по таким новым для двустороннего диалога темам, как сближение интеграционных блоков - например, СЕЛАК и ЕАЭС (Евразийский экономический союз), а также МЕРКОСУР и ЕАЭС. 
Газпром и государственная нефтегазовая компании Аргентины YPF подписали Меморандум о сотрудничестве в сфере энергетики. Речь шла о совместной реализации новых проектов в геологоразведке, добыче и транспортировке углеводородов, производстве электроэнергии на аргентинской территории, маркетинговых исследованиях нефтегазового сектора, строительстве, содержании и модернизации инфраструктуры, связанной с транспортировкой нефти и газа в Аргентине [Газпром...].

Аргентинская сторона придавала большое значение данному документу. В последние годы страна потеряла способность к самообеспечению энергоресурсами, и власти возлагали большие надежды на открытое в 2011 г. в провинции Неукен крупное месторождение Vaca Muerta', которое разрабатывала YPF. Однако в силу ряда причин YPF не смогла привлечь к совместным работам крупных партнеров и необходимые многомиллиардные инвестиции. Подписанный с «Газпромом» документ позволял аргентинскому правительству и руководству компании надеяться на серьезный прорыв в «энергетическом» вопросе. Общая стоимость проектов только по строительству электростанций с использованием разных источников энергии: органического (ТЭС, ТЭЦ), ядерного (АЭС) топлива или энергии водных масс (ГЭС), заключенных в тот период, равнялась примерно 5 млрд долл. [Россия...].

Всего за два президентских мандата К. Фернандес де Киршнер (с 2007 по 2015 г.) Аргентина подписала с Россией в общей сложности более 60 различных двусторонних документов.

\section{Перемены в Аргентине и новая внешняя политика}

Смена руководства в Аргентине в декабре 2015 г. привела к пересмотру парадигмы развития страны, в том числе к развороту в отношениях с остальным миром. Новый хозяин Розового дома (резиденции президента Аргентины) Маурисио Макри взял курс на расширение круга политических и деловых партнеров Аргентины на международной арене, улучшение отношений с теми государствами, взаимодействие с которыми могло принести крупные инвестиции и современные технологии (США, Япония, государства члены ЕС). Таким образом, аргентинская внешняя политика должна была стать максимально прагматичной, направленной на экономическое развитие страны [Яковлева Политика...].

Именно поэтому, несмотря на многочисленные пессимистические прогнозы и политические спекуляции, двусторонние контакты между РФ и ее южноамериканским партнером не претерпели существенных изменений. Обеим сторонам хватило здравого смысла, чтобы не прерывать процесс выстраивания всеобъемлющего стратегического партнерства. Пример тому - результаты визита министра иностранных дел и культа Аргентины Сусаны Малькорры в Москву в апреле 2016 г. и ее переговоров с С.В. Лавровым.

1 Сланцевый бассейн Vaca Muerta располагается в провинции Неукен (центральная части Аргентины). Запасы углеводородов были открыты там в 2011 г, а их разведанный объем указывает на то, что это одно из крупнейших сланцевых месторождений в мире. 
Стороны подчеркнули, что визит состоялся «в рамках установленных отношений всеобъемлющего стратегического партнерства», и отметили взаимное стремление «расширять и дифференцировать двустороннюю торговлю, осуществлять взаимодействие в сфере энергетики, противодействия незаконному обороту наркотиков и терроризму, а также в научно-технической области - с акцентом на исследовании космоса». В аргентинской прессе визит расценили как «ясный сигнал» о намерении новых властей углубить всеобъемлющий стратегический союз. «На Малькорру возложена миссия передать Кремлю, что Аргентина не замыкается лишь на отношениях с США, а, наоборот, проводит политику открытых дверей, которая включает в себя и Россию», - приводили СМИ слова высокопоставленного сотрудника аргентинского МИД [Malcorra].

В июне 2016 г. по инициативе аргентинской стороны состоялся телефонный разговор В.В. Путина с М. Макри, в ходе которого обсуждались вопросы двустороннего торгово-экономического сотрудничества с акцентом на приоритетные проекты в сфере энергетики. В начале ноября 2016 г. в Буэнос-Айресе прошло 12-е заседание Российско-аргентинской межправительственной комиссии по торгово-экономическому сотрудничеству. Эксперты рабочих групп рассмотрели возможности снятия имеющихся барьеров, препятствующих росту товарооборота. На заседании обсуждались перспективы взаимодействия российских и аргентинских предприятий в сфере энергетики. В последние годы стало очевидно, что энергетика и торговля товарами являются наиболее актуальными сферами двустороннего сотрудничества.

\section{Энергетика - перспективная сфера сотрудничества}

K числу наиболее перспективных направлений взаимодействия между Россией и Аргентиной в энергетической сфере можно отнести участие российских компаний в:

- проектах по разведке и добыче нефти и газа на территории Аргентины;

- строительстве нефте- и газопроводов, нефтеперерабатывающих заводов;

- поставках оборудования;

- создании совместных предприятий в области производства арматуры для нефтяных и газовых скважин;

- сооружении ГЭС, модернизации и ремонте действующих ГЭС и ТЭС.

Российские компании обладают оборудованием и технологиями производства сжиженного природного газа, его хранения и транспортировки. Россия располагает уникальной технологией по транспортировке электроэнергии на большие расстояния, позволяющей существенно сокращать потери энергии и снижать операционные расходы [Consejo...].

Проблемы сотрудничества в этой отрасли обсуждались во время встречи президентов РФ и Аргентины на полях саммита «Группы двадцати» (Ханчжоу, Китай, сентябрь 2016 г.). В частности, затрагивалась тема российского участия в эксплуатации аргентинских месторождений нефти и газа. Большой интерес к сотрудничеству проявляли такие гиганты, как «Роснефть» и «Эриэлл Нефтегазсервис» (российское подразделение группы ERIELL), которые, по сообщениям аргентинской прессы, начали работать 
в Аргентине через местных субконтракторов [Vаса...]. Был подтвержден и интерес аргентинских властей к строительству ГЭС Chihuido-1 с участием РФ, однако дело застопорилось из-за финансовых разногласий. Не договорившись с российской стороной, аргентинцы решили обратиться к помощи Китая. В ходе визита высокопоставленных чиновников в Пекин в ноябре 2016 г. были достигнуты договоренности о китайских инвестициях в проект, превышающих 2 млрд долл., и о начале строительства в 2017 г. - уже с помощью китайских компаний [Rusia...].

Воспользовавшись заминкой в аргентинско-российском взаимодействии, на рынках Аргентины активизировались и другие конкуренты. В сентябре 2017 г. прошли переговоры, а в октябре правительство провинции Неукен подписало контракт на разработку участка месторождения Vaca Muerta с местным филиалом американской ExxonMobil, как основным оператором пилотного проекта (с долей 80\%), и его аргентинскими партнерами Gas у Petroleo del Neuquén и Americas Petrogas Argentina (по 10\%). Первоначальный объем инвестиций составит около 200 млн долл. [ExxonMobil's...]. Учитывая возрастающую конкуренцию на этом рынке, российским структурам необходимо проявлять максимальную гибкость в целях сохранения имеющегося задела и дальнейшего его расширения. Очевидно, что наши страны обладают огромным потенциалом сотрудничества в энергетической сфере, и важным залогом успешной реализации всех наработок является наличие политической воли к удержанию высокого уровня взаимодействия.

\section{Взаимная торговля}

На двусторонней встрече президентов РФ и Аргентины В.В. Путин отметил, что Россия надеется на увеличение поставок аргентинского продовольствия. М. Макри в свою очередь заверил российского лидера в том, что его страна обладает огромным сельскохозяйственным потенциалом [Los detalles...].

Для конкретизации торговой повестки Москву посетил министр агроиндустрии Аргентины Рикардо Буриайле. В ходе рабочей встречи с министром сельского хозяйства РФ А.Н. Ткачевым были обсуждены вопросы торговли сельхозпродукцией и продовольствием. Россия, по словам Ткачева, готова наращивать импорт аргентинских фруктов (груш, яблок, цитрусовых), а также морепродуктов и молочной продукции. В свою очередь, российские предприятия способны выйти на рынок Аргентины не только с энергетическим сырьем и промышленными изделиями, но и с отдельными видами сельхозпродукции, что, по мнению российского министра, позволит выровнять торговый баланс. Р. Буриайле подтвердил заинтересованность Аргентины в увеличении товарооборота между двумя странами и указал на готовность Буэнос-Айреса расширять импорт российских удобрений, а также сельскохозяйственной техники. Оба министра отметили важность расширения номенклатуры товаров как экспорта, так и импорта [Торговля между Россией и Аргентиной...].

В настоящее время доля Аргентины в общем внешнеторговом обороте РФ является сравнительно небольшой, страна по объему товарооборота занимает лишь третье 
место среди государств Южной Америки (табл.). В 2016 г. главными торговыми партнерами России в этом регионе были Бразилия (0,92\% от всего внешнеторгового оборота России), Эквадор (0,30\%), Аргентина (0,18\%), Парагвай $(0,15 \%)$ и Чили (0,14\%). При этом Аргентина не попала в пятерку реципиентов российского экспорта, где лидировали Бразилия (0,63\% от общего экспорта России), Венесуэла (0,13\%), Перу (0,073\%), Колумбия (0,07\%) и Эквадор (0,066\%). Среди южноамериканских стран - экспортеров продукции на российский рынок в 2016 г. первое место заняла Бразилия (1,38\% от общего импорта России), за ней шли Эквадор (0,66\%) и Парагвай (0,38\%). Аргентина оказалась на четвертом месте (0,38\%), Чили - на пятом (0,33\%) [Торговля между Россией и странами Южной Америки...].

Таблица

\section{Внешняя торговля Российской Федерации в 2016 г. (млрд долл.)}

$\begin{array}{lc}\text { Общий объем внешней торговли РФ } & 469,1 \\ \text { - экспорт } & 285,5 \\ \text { - импорт } & 183,6 \\ \text { Внешнеторговый оборот РФ со странами дальнего зарубежья } & 413,4 \\ \text { Внешнеторговый оборот РФ со странами ЛАКБ } & 12,1 \\ \text { - экспорт } & 5,2 \\ \text { - импорт } & 6,9 \\ \text { Внешнеторговый оборот РФ с Аргентиной } & 0,847 \\ \text { - экспорт } & 0,163 \\ \text { - импорт } & 0,684\end{array}$

Источник: ПРОВЭД. - URL: провэд.рф/analytics/research/40407-vneshnyaya-topgovlya-possii-v-2016godu-tsifpy-i-fakty.htm...; Trade map. - URL: trademap.org/Bilateral_TS.aspx?nvpm=1|643||15|TOTAL|||2|1|1 $|2| 2|1| 1|1| 1$ (date of access: 20.12.2017).

Как можно понять из таблицы, Россия также не входит в число основных торгово-экономических партнеров Аргентины. Из общего объема аргентинского экспорта (57,7 млрд долл. в 2016 г.) на долю нашей страны приходилось всего лишь около 1,2\%. Более того, РФ имеет отрицательное сальдо торгового баланса с этой страной (521 млн долл. в 2016 г.), которое, правда, демонстрирует тенденцию к снижению по сравнению с предыдущими годами (895,1 млн долл. в 2014 г., 705,1 млн - в 2015 г.) [Trade map]. Вместе с тем российский рынок рассматривается аргентинцами как один из наиболее перспективных с точки зрения сбыта своей продукции, прежде всего сельскохозяйственной. В современной геополитической обстановке, в условиях санкционной войны значение Аргентины как поставщика продуктов питания и сельскохозяйственного сырья на российский рынок может возрасти. Иначе говоря, экономические санкции Евросоюза и США по отношению к России предоставляют дополнительные возможности аргентинскому агропромышленному сектору расширить свои позиции на российском рынке [Argentina...]. Чтобы обеспечить сбалансированный и устойчивый рост торговли, нужно наращивать и российский экспорт. На это нацелены многочисленные программы и планы, принятые в рамках построения отношений всеобъемлющего стратегического партнерства. 
Российско-латиноамериканские связи привлекают внимание зарубежных экспертов и дают пищу самым различным интерпретациям. По мнению некоторых западных исследователей, набирающее силу сотрудничество интересно для Кремля с геополитической точки зрения, а реальной движущей силой активизации России в Западном полушарии является глобальное соперничество с Китаем. Регулярные анонсы об участии России в масштабных проектах в странах ЛАКБ нацелены якобы на «успокоение» российских граждан и опровержение сведений об изоляции страны на международной арене и возможной нехватке продовольствия в случае ужесточения западных санкций [Villers]. Признавая за Москвой определенные успехи в деле сближения с Латинской Америкой, отдельные наблюдатели сомневаются в возможности их практической реализации из-за существующих финансово-экономических проблем: девальвации рубля, ограниченного доступа к источникам международного кредитования, а также невысокой репутации многих российских банков и опасения новых санкций со стороны США.

Но есть и другие мнения. Так, почти все специалисты, опрошенные изданием Russia Beyond, убеждены, что отношения России со странами Латинской Америки, в частности, с Аргентиной, развиваются поступательно, а приход в Белый дом Д. Трампа открывает двери для новых геополитических сценариев на латиноамериканском пространстве, в которых России может быть отведена ключевая роль [Claves...].

Очевидно, что такое понимание ситуации присутствует и в верхнем эшелоне аргентинской власти. Так, в ноябре 2017 г. состоялся уже второй за два года визит в Москву министра иностранных дел и культа Аргентины, на этот раз Хорхе Фори, сменившего на посту С. Малькорру. В ходе переговоров с С.В. Лавровым обсуждались актуальные вопросы глобальной повестки дня, совместные действия на международных площадках. Из опубликованного коммюнике известно, что в ходе визита были согласованы двусторонние соглашения о военно-техническом сотрудничестве, рыболовстве, взаимном признании документов об образовании. Стороны договорились «предпринять дополнительные шаги в интересах эффективной реализации совместных инвестиционных проектов, в том числе в области энергетики, включая атомную, исследования и мирного использования космоса, создания логистической, портовой и железнодорожной инфраструктуры» [Выступление...]. В начале декабря в Буэнос-Айрес с официальным визитом в сопровождении большой делегации прибыл секретарь Совета безопасности РФ Н.П. Патрушев, обсуждавший с М. Макри вопросы военно-технического сотрудничества. По итогам визита был подписан Меморандум о сотрудничестве, который подразумевает проведение консультаций и регулярный обмен мнениями по представляющим взаимный интерес стратегическим вопросам региональной и международной безопасности [Nikolai Patrushev...].

Большое значение для практического наполнения стратегического сотрудничества России и Аргентины имеет деятельность представительств российских организаций и корпораций в этой латиноамериканской стране. Наряду с посольством и торгпредством РФ в Буэнос-Айресе функционировали представительства Федеральной таможенной службы РФ, Государственной корпорации по атомной энергии «Росатом», 
Государственной корпорации «Ростехнологии», ФАУ «Российский морской регистр судоходства», ОАО «Силовые машины». В конце 2016 г. этот список пополнился представительством АО «Российский экспортный центр», в задачи которого входит содействие продвижению на аргентинский рынок российской продукции, включая высокотехнологичные товары.

7-8 ноября 2017 г. в Буэнос-Айресе прошел первый совместный деловой форум советов предпринимателей «Россия - Аргентина» и «Аргентина - Россия», где состоялись презентации бизнес-проектов. Главами советов -Андреем Гурьевым и Антонио Эстрани-и-Хендре - был подписан меморандум о сотрудничестве. Такая практика, безусловно, призвана помочь нашим товаропроизводителям активнее осваивать достаточно емкий аргентинский рынок. По мнению А. Гурьева, генерального директора ПАО «Фосагро», «2017 год стал прорывным для России и Аргентины в части укрепления и расширения существующего сотрудничества». Это подтвердил руководитель Россельхознадзора, председатель российской части межправительственной российскоаргентинской комиссии по торгово-экономическому и научно-техническому сотрудничеству С. Данкверт, уточнивший, что в 2017 г. возобновился рост товарооборота, который в январе-августе увеличился на $11,5 \%$ - до 847 млн долл. - и по итогам года должен приблизиться к одному млрд долл. [Гурьев...].

Аргентина и Россия находятся только в самом начале пути к получению максимальной отдачи от взаимодействия в различных отраслях хозяйства. В последние годы двустороннее сотрудничество наполняется новым содержанием. Планируемый на конец января 2018 г. визит президента М. Макри в Москву откроет, без сомнения, новую страницу в двусторонних отношениях. Наши страны в 2018 г. будут организаторами двух крупных международных мероприятий: чемпионата мира по футболу в России и саммита «Группы двадцати» в Аргентине. Таким образом, президенты двух стран встретятся друг с другом трижды за один календарный год, что станет беспрецедентным фактом в истории российско-аргентинских отношений.

\section{Литература:}

Астахов Е.М. Латиноамериканское «ближнее зарубежье» США при администрации Д. Трампа // Международная жизнь. 19.10.2017. - URL: interaffairs.ru/news/show/18579 (дата обращения: 20.12.2017).

Давыдов В.М. Стратегическое партнерство в контексте российско-латиноамериканских отношений // Вестник Российской Академии наук. 2016. № 4. С. 304-316.

Торговля между Россией и Аргентиной в 2016 г. // Внешняя торговля России. - URL: russiantrade.com/reports-and-reviews/2017-02/torgovlya-mezhdu-rossiey-i-argentinoy-v-2016-g/ (дата обращения: 20.12.2017).

Торговля между Россией и странами Южной Америки в 2016 г. // Внешняя торговля России. URL: russian-trade.com/reports-and-reviews/2017-02/torgovlya-mezhdu-rossiey-i-stranamiyuzhnoy-ameriki-v-2016-g/ (дата обращения: 20.12.2017).

Выступление и ответы на вопросы СМИ // МИД РФ. 16.11.2017. - URL: mid.ru/foreign_policy/ news/-/asset_publisher/cKNonkJE02Bw/content/id/2952813 (дата обращения: 20.12.2017). 
«Газпром» и YPF подписали Меморандум о сотрудничестве. - URL: gazprom.ru/press/ news/2015/april/article224600/ (дата обращения: 14.12.2017).

Гурьев: 2017 год стал прорывным для России и Аргентины в укреплении связей // РИА Новости. 15.11.2017. - URL: ria.ru/economy/20171115/1508866188.html (дата обращения: 16.11.2017.).

Заявления для прессы по итогам российско-аргентинских переговоров // Сайт президента PФ. - URL: kremlin.ru/events/president/transcripts/46210 (дата обращения: 21.12.2017).

Интервью В.В. Путина латиноамериканскому агентству «Пренса Латина» и российскому агентству ИТАР-ТАСС 11 июля 2014 г. // Сайт президента PФ. - URL: special.kremlin.ru/catalog/ countries/AR/events/46190 (дата обращения: 18.12.2017).

Концепция внешней политики России. 15 июля 2088 г. // Сайт президента PФ. - URL: kremlin. ru/acts/news/785 (дата обращения: 28.12.2017).

О состоянии и перспективах развития сотрудничества России с государствами Латинской Америки // МИД РФ. - URL: mid.ru/problemy-vzaimootnosenij-so-stranami-latinskoj-ameriki-ikaribskogo-bassejna (дата обращения: 10.12.2017).

Россия и Аргентина договорились об увеличении взаимных поставок сельхозпродукции // Минсельхоз России. 21.10.2016. - URL: mcx.ru/news/news /show/55812.htm (дата обращения: 15.01.2017).

Россия и Аргентина подписали 20 соглашений - и это только начало // Ино TV. - URL: russian. rt.com/inotv/2015-04-24/Rossiya-i-Argentina-podpisali-20 (дата обращения: 14.12.2017).

Совместное заявление Российской Федерации и Аргентинской Республики о построении отношений о стратегическом партнерстве // Сайт президента PФ. - URL: kremlin.ru/ supplement/222 (дата обращения: 10.12.2017).

Яковлев П.П. Россия - Латинская Америка: новый этап // Перспективы. - URL: perspektivy. info/table/rossija_latinskaja_amerika_novyj_etap_2010-05-14.htm (дата обращения: 10.12.2017).

Яковлев П.П. Россия и Латинская Америка: параметры стратегического партнерства // Латинская Америка. 2016. № 1. С. 5-14.

Яковлев П.П. Тенденции развития и сотрудничество с Россией. М. 2005.

Яковлев П.П. «Эффект Трампа» или конец глобализации? М. 2017.

Яковлева Н.М. Архипелаг раздора (к 30-летию Фолклендской (Мальвинской) войны) // Перспективы. - URL: perspektivy.info/oykumena/politika/arkhipelag_razdora_k_30-letiju_ folklendskoj_malvinskoj_vojny_2012-03-13.htm (дата обращения: 10.12.2017).

Яковлева Н.М. Договорно-правовая база двустороннего сотрудничества между Россией и Аргентиной. - URL: ilaran.ru/?n=590 (дата обращения: 10.12.2017).

Яковлева Н.М. Политика «открытых дверей» по-аргентински // Латинская Америка. 2017. № 3. C. 15-29.

Argentina y Rusia: relación entre “dos necesitados" // Clarín. Buenos Aires. 04.05.2016.

Claves para la relación Argentina-Rusia en 2017 // Notícias Urbanas. Buenos Aires. 28.12.2017.

Consejo Empresario Argentino-Ruso. - URL: cear.org/ru/proyectos-en-curso/ (date of access 10.01.2017).

ExxonMobil's Investment Plan Approved for Los Toldos I South Block in Argentina. - URL: oilandgaspeople.com/news/15398/exxonmobils-investment-plan-approved-for-los-toldos-isouth-block-in-argentina/ (date of access: 21.12.2017).

Las relaciones entre Argentina y Rusia pasan por su mejor momento. - URL: es.rbth.com/ 
internacional/2014/01/16/las_relaciones_entre_argentina_y_rusia_pasan_por_su_mejor_ momen_36391 (date of access: 15.11.2017).

Los detalles de la reunión entre Macri y Putin // La Nación. Buenos Aires, 5.09.2016.

Malcorra viajó a Rusia para revisar acuerdos y relanzar las relaciones // La Nación. 12.04.2016.

Nikolai Patrushev, el mítico ex KGB, se reunió con Mauricio Macri. - URL: infobae.com/ politica/2017/12/05/nikolai-patrushev-el-mitico-ex-kgb-se-reunio-con-mauricio-macri/ (date of access: 15.11.2017).

Russia beyond the Headlines. 27.12.2016 // Diariamente. Neuquén. 09.12.2016. - URL: diariamenteneuquen.com.ar/V3.0/2016/12/09/chihuido-y-otras-obras-fueron-ofrecidas-a-lainversion-china/ (date of access 10.01.2017).

Trade map. - URL: trademap.org/Bilateral_TS.aspx (date of access: 20.12.2017).

Síntesis de los acuerdos suscriptos con Rusia. - URL: cfkargentina.com/sintesis-de-los-acuerdossuscriptos-con-rusia/ (date of access: 21.12.2017).

Vaca Muerta News. Neuquén. 12.07.2015. - URL: vacamuertanews. com.ar/ver_noticia. php?id=20150712100401 (date of access: 10.01.2017).

Villers Negroponte D. El juego de Putin // Americas Quarterly. - URL: americasquarterly.org/ content/el-juego-de-putin-0 (date of access 20.11.2017). 